\title{
Is cruising along European rivers primarily intended for seniors and workers from Eastern Europe?
}

\author{
Irma Erdeji ${ }^{*}$, Aleksandra Dragin ${ }^{\mathrm{A}}$ \\ Received: March 1, 2016 | Revised: April 12, 2017 | Accepted: May 27, 2017
}

DOI: 10.18421/GP21.02-05

\begin{abstract}
The subject of the paper is river cruising along the rivers of Europe in Belgium, the Netherlands, Germany, Switzerland, France, Austria, Slovakia, Hungary, Croatia, Serbia, Bulgaria, Romania and Italy. The research needed to determine the trends in terms of consumers and labour force, particularly considering great political and economic changes in Europe (and the world) in the last ten years. The aims of the research were set in relation to the following: to determine the profile of a tourist as well as the crew members. This paper is based on empirical and theoretical research. It combines quantitative primary and secondary as well as qualitative data collection (interview). Primary data was collected from the "Uniworld" company by analysing crew manifests in order to define the demographical profile of the employees. Secondary data collection was used to define the profile of the tourist, where latest relevant publications were consulted. Qualitative method was used to gain more insight in the latest trends of River Cruising by interweaving the managers of the "Uniworld" company. It was determined that "baby boomers" are no longer prevalent on the cruise ships, but the "millennials" cohort are on the rise. Such changes will require a new approach among the cruising companies - in terms of the concept of service delivery and marketing. However, among employees there is no significant change, suggesting that this type of job market is tightly regulated by EU regulations. This research offers valuable data in the field of tourism destination management, as well as the needs of some stakeholders, especially in terms of human resources management and management of strategic development issues. This is important both for the countries which already have positioned themselves on the cruising market as well as for emerging destinations.
\end{abstract}

Keywords: River cruising, labour force composition, economic impact, tourist profile, trends and challenges.

\section{Introduction}

Cruising along the oceans and rivers by transoceanic and river cruise ships enables a unique access to numerous popular tourist destinations around the world. Cruising is being defined as steering passenger ships solely for the purpose of enjoyment. These ships are not included in the traffic sector such as ferries or cargo ships. For the cruise ship, it is not a matter of going from-to points in space; the voyage is a part of holiday package (Cartwright, Baird, 1999). It is well-known fact that the cruise tourism has expanded greatly. With nearly $\$ 40$ billion income in 2015 (Cruise Lines International Association - CLIA, 2015), over 20 million tourists, 348,930 work places in Europe in 2015 (The Florida-Caribbean Cruise Association, FCCA, 2015), while in 2012 there were around half a million work places in the world (Gibson, 2012) directly or indirectly in the cruise tourism sector; this sector has become a significant segment of tourism and it is increasingly drawing attention of the researchers.

\footnotetext{
A Faculty of Sciences, University of Novi Sad, Trg Dositeja Obradovića 3, 21000 Novi Sad; irmaing@gmail.com

* Corresponding author: Irma Erdeji, e-mail: irmaing@gmail.com
} 
Globalization has encouraged competitiveness between the companies within the service sector, and as stated by Schneider and Bowen (2010), the companies should exceed expectations of the consumers in order to ensure satisfaction. Such high level of performance and engagement of the employees is the key element in providing and maintaining a high level of service (Li,et al., 2012).

Cruising is very appealing to many tourist as it is being characterised as safe, suitable for social bonding, completely user-oriented and focused on providing the service (Cartwright, Baird, 1999). The ship is a safe, mobile base, a 'home' far away from home, while the tourist is 'tasting' the tourist destination. Cruising is segmented market, with highly differentiated products. The market can be divided into four segments: mass, middle, luxury and specialty (Hobson, 1993).Dickinson and Vladimir (1997) point out that the first mass market-oriented cruise company, Carnival Cruise Lines, advertised their vessels as holiday destinations but not the ports of call. Throughout its development, the cruise tourism sector adapted to the demands of its users - tourists; innovations have been introduced, in terms of new destinations, cruise designs, adjustments and introduction of new services and benefits, both on the cruise ship as well as on land, where tourists were offered a wide array of activities. Cruising companies are offering thematic cruises as well as cruises of different lengths in order to satisfy the ever-changing tourists' demands (FCCA, 2015).

The number of tourists cruising is in constant rise (Internet 1). It is assumed, that this trend will continue and that in 2019 the number of tourists on cruise ships will surpass 25 million. In 2014 individual tourists contributed with an average of $\$ 2,123$ to the income generated by the global cruise tourism industry. Most tourists cruise along the territory of North America. Accordingly, the share of North America in the global sector is the highest, valuing over \$21 billion. Howev-

Table 1. The capacities of tourist cruising sector around the world

\begin{tabular}{|l|c|}
\hline Region & $\begin{array}{c}\text { Share of the total } \\
\text { capacity in 2015 (\%) }\end{array}$ \\
\hline The Caribbean/the Bahamas & 35.5 \\
\hline The Mediterranean & 19.5 \\
\hline Europe (excluding the Mediterranean) & 10.6 \\
\hline Asia & 6.0 \\
\hline $\begin{array}{l}\text { Australia, New Zealand/the South } \\
\text { Pacific }\end{array}$ & 6.0 \\
\hline Alaska & 4.5 \\
\hline South America & 2.9 \\
\hline Other & 15.0 \\
\hline
\end{tabular}

Source: FCCA, 2015 er, in recent years, the US tourists have shown less enthusiasm for holiday cruising. Still, it is encouraging that cruising along the European rivers is very popular among the US tourists (Internet 1).

In the information and communication era, the access to global market is easy and it is possible for the users to globally share their recommendationsbut also their critiques.

It is not easy to keep the negative reviews of being read by global audience. Therefore, the companies are much more focused on achieving satisfaction of their users. The aim of this research is to determine the common profile of a typical European cursing tourist and to reveal their age.

What needs to be answered is whether the older population (pensioners), who are not very active on social media, are still prevalent on cruise ships, or there has been a shift in the age structure.

There is a competition among the cruise companies in terms of conquering the emissive markets but also the labour force markets. For many service-oriented companies, front-line employees are the source of differentiation and competitiveness of the company as a whole (Brown, King, 2002). This is why another aim of this research is to determine the demographic characteristics (gender, nationality) of the employees on ships which cruise along the European rivers and their work positions.

\section{Study Background}

Previous publications that dealt with cruises were mainly based on cruises along the oceans and seas, focusing on the economic and sociological problems (Foster, 1986; Li, Petrick, 2008; Duman, Mattila, 2005; Gabe, et al., 2006; Jaakson, 2004; Dwyer, Forsyth, 1996, 1998; Mescon, Vosikis, 1985; Braun, et al., 2002; Brida, Aguire, 2008; Larsen, et al., 2013; Veronneau, Roy, 2009).

However, there are a few studies dealing with cruises along the European receptive areas, especially along the rivers, and all researchers dealt with cruises along the Pan-European Corridor VII (Dragin, 2008, 2010; Dragin, et al., 2006, 2007, 2008, 2009, 2014).This paper extends the research to include the cruise ships which cruise along nine rivers: the Danube, the Rhine, the Main, the Moselle, the Seine, the Rhone, the Garonne, the Dordogneand the Po. Apart from this, the structure of tourists and the crew on European river cruise ships needed to be determined once again, as there have been some great changes in the global economy and politics in the last ten years,since the previously mentioned research.The global economic crisis has affected the consumers' purchasing power, i.e. it caused changes in the consumers' behaviour, as did also re- 
Table 2. Direct economic impact of the cruise tourism sector on other industry sectors

\begin{tabular}{|l|c|c|c|}
\hline Industry sector & Cost in millions in Euros & Work places number & $\begin{array}{c}\text { Employees' salary in millions } \\
\text { in Euros }\end{array}$ \\
\hline Agriculture, mining and building & 20 & 171.000 & 4 \\
\hline Production & 7.999 & 42.559 & 1.707 \\
\hline Trade & 812 & 11.150 & 222 \\
\hline Traffic & 3.696 & 21.902 & 805 \\
\hline Tourism and hospitality & 407 & 6.421 & 143 \\
\hline Financials & 1.576 & 13.419 & 463 \\
\hline Private services & 647 & 9.336 & 266 \\
\hline Employees on cruise ships & 1.480 & 64.873 & 1.480 \\
\hline Total & 16.637 & 169.831 & 5.090 \\
\hline
\end{tabular}

Source: CLIA, 2015

cent terrorist attacks in the USA and Europe. Wars in the Middle East have also caused millions of people to migrate to Europe. Changes on the labour force market of the EU are expected. Finally, Romania's and Bulgaria's joining the EU enabled their residents to move to other, more developed countries of the EU but also to apply for jobs in the EU without having to change their place of residence.

There were 348,930 work places in the cruise tourism sector in Europe in 2015. It is being estimated that 59,500 European citizens were employed on cruise ships as captains, officers and other maritime crew. The consumption generated by the organisers of the cruises enabled opening new work places, as well as income in other sectors directly or indirectly related to tourism and the cruise tourism sector, in both emissive but also in receptive countries (CLIA, 2015).

Considering the demographic profile of tourists on cruises, most of the participants are married couples, especially generations born after the World War II (baby boomers) (CLIA, 2007), with steady and permanently established travelling habits and are more experienced, wealthier and more educated clientele (CLIA, 2007). Their tourist needs should be fulfilled in every qualitative sense, i.e. employees should possess social and cultural skills that underpin customer service relationships or interpersonal communications (Gibson, 2012).

\section{Samples and methods}

This paper is based on empirical and theoretical research and it was conducted in the period between September and November 2016. It combines quantitative primary and secondary, as well as qualitative data collection (interview). Secondary data collection was used to define the profile of the tourist, where latest relevant publications were consulted. All primary data were collected from the manifests of the "Uni- world" company. Data was acquired on the structure according to gender, country of origin and work positions of 689 crew members from 13 luxury cruise ships. These cruise ships cruise along the European rivers: the Rhine, the Main, the Danube, the Moselle, the Seine, the Rhône, the Garonne, the Dordogne and the Po.

Qualitative method was used to gain more insight in the latest trends of River Cruising. In the second phase, an interview was used in order to gain deeper understanding of the river cruise employees. Ten managers of the "Uniworld" company were interviewed. The interview questions were related to trends in cruising sector and challenges the companies face - whether the developments on the global political scene affect the demand for cruises along Europe. Whether river cruising is popular mostly among pensioners. The third query was whether it is being planned to develop a new tourist product. During the process of evaluating the resultsthe descriptivestatistical method (frequency distribution) was used.

\section{Research results and discussion}

It is often being said that cruisingis an "expensive pleasure" intended for pensioners. Is this still the case? In recent years the situation has been changing. So far, "baby boomers", the generations born between 1954 and 1964,have been the main target marketing segment of the cruise ships around the world, while the river cruises had even older cohorts, the generations born in the decades after the first but also the second world war (Dragin, 2008; Internet 2). Changes in guests' structure is evident in a higher presence of the so-called cohort millennials (CLIA, 2014). This has been noted by the employees on the river cruise ships, who are aware that their relationship with the consumers as well as their offer,will need to have a different concept in the future. Thus, there will be more 
tourists born between 1977 and 2000, i.e. the generation that enters their maturity in the $21^{\text {st }}$ century, which is already the case on the seas and oceans (Internet 3).

Based on the more detailed data published by the CLIA (2014), an increasing number of tourists are of different ages. The average age of a tourist that cruises is 49 , which is a significant change compared to the former average of 65 (Dragin, 2010). The share of tourists is almost identical for age groups 30-39, 50-59 and $60-74$ and is $23 \%, 24 \%$ and $24 \%$ (CLIA, 2014).

In order to satisfy the needs of the new marketing segment, some companies have decided to adjust their product to these new consumers in 2018. Starting from next year, we will witness two ships on European rivers intended exclusively for younger tourists, where the complete offer and organisation of providing services will be based on detailed market research and consideration for demand.

Social networks have become the basic medium for a rapid flow of information, both desirable as well as undesirable (Bolton, et al., 2013).Portals such as Cruise Critic, Travel and Leisure or Condé Nast are very important source of information in the world of tourism (and cruise ships), for the offer as well as the demand. Here, one can find reviews based on tourists' vote for the best cruising organisers, the best ships, destinations and many other categories. For example, Condé Nast Traveller readers rank the best cruise lines in the world in Readers' Choice Awards survey, including: large ships (more than 2,500 passengers), medium ships (500 to 2,500 passengers), small ships (fewer than 500 passengers) and river cruises (Internet 4); or by Cruise Critic: Cruise ships' Choice Awards; Editors' Picks Awards: Ocean Cruise Lines; Best Luxury River Cruise Line etc. (Internet 5). Also, all tourists, users of services can easily describe their experience on the cruise ship. More than ever, it is easy to access wide population, but it is also more difficult to maintain the competitiveness. Apart from this, message boards, blogs, YouTube, Facebook, Instagram, where tourists can share their experience with hundreds of friends/followers, are also very popular. Fifty-six percent of millennials report they are usually either one of the very first to try new technology or are among the first group to try a new technology, $46 \%$ of millennials report having more than 200 Facebook friends and $46 \%$ of millennials post original photos or videos online that they themselves have created. Eighty percent of millennials want brands to entertain them; $40 \%$ want to participate in co-creation of products and brands; $70 \%$ feel responsibility to share feedback with companies after a good or bad experience; $69 \%$ say they crave adventure (Internet 3 ).

Another aim of the research was to determine the structure of the crew on the cruise ships on Europe- an rivers. This is especially important since there has been a globalisation of business management, thus, a cruising company may have its headquarters, for example in the USA or Switzerland, the ship is registered in Malta, while the captain comes from the Netherlands (Dragin, 2008).

The following data (table 3 ) was acquiredby accessing the lists of the crew members on 13 river cruise ships which cruise along European rivers: the Rein, the Main, the Danube, the Moselle, the Seine, the Rhône, the Garonne, the Dordogne and the Po.

It was determined that the crew on river cruise ships come from 26 countries, mostly European (except for three countries: Columbia, the Philippines and India, with a percentage share less than $1 \%$ ). Most of the employees come from Romania - almost one in three (29.65\%), then Bulgaria 22.53\%, Hungary 9.74\% and Serbia $7.99 \%$. The fifth place according to the number of employees is France $7.85 \%$. The employees who come from Croatia are in the ninth place, with a share of $1.16 \%$, Bosnia and Herzegovina is in the 13 th place, with $0.58 \%$. The group 'other' in the table 3 represents the total number of employees for the countries where the frequency is less than three: Sweden (2), Macedonia (2), Spain (2), Philippines (2), Austria (2), Montenegro (1), Switzerland (1), Lithuania (1), Colombia (1), India (1), Ukraine (1), and United Kingdom (1).

When these results are compared to the research of the Pan-European Corridor VII (Dragin, et al., 2010), in some cases, the situation is similar. In this research, the employees from Romania were prevalent (24.5\%), then the employees from Ukraine (21.9\%), compared to the recorded $0.15 \%$. Hungarians are also in the third place, with a share of $14.1 \%$. The percentage share of the Slovakians declined significantly, from $13.2 \%$ to $6.25 \%$, and the number of the employees from Serbia increased from $4 \%$ to $7.99 \%$. Two significant differences were observed in the share of the employees from France and the Netherlands. In the 2010 research the French made $0.9 \%$, and the Dutch $1.2 \%$ out of the total number of employees, compared to $7.85 \%$ and $4.65 \%$ respectively, in this research. An increase in the number of employees from France and the decline of the employees from Romania lies in the fact that the research failed to focus on the Danube as much. An interesting fact is that there are yet no employees from the Middle East.

When the structure of the employees is analysed according to gender, it is evident that men prevail (517 employees, $75.04 \%$ ) comparing to women (172 employees, $24.96 \%$ ), primarily due in the nautical department.

The research (Dragin, 2008; Dragin, et al., 2014) determined that male employees also prevail compared to female employees (64:36), particularly among the nautical crew. Gibson (2012) had similar 
Table 3. Structure of the crew on the 13 analysed cruise shipsaccording to nationality and gender

\begin{tabular}{|l|c|c|c|c|c|c|}
\hline Country of origin & N & $\%$ & Male N & $\begin{array}{c}\text { \% within } \\
\text { nationality }\end{array}$ & Female N & $\begin{array}{c}\% \text { within } \\
\text { nationality }\end{array}$ \\
\hline Romania & 204 & 29.65 & 147 & 72.06 & 57 & 27.94 \\
\hline Bulgaria & 155 & 22.53 & 120 & 77.42 & 35 & 22.58 \\
\hline Hungary & 67 & 9.74 & 43 & 64.18 & 24 & 35.82 \\
\hline Serbia & 55 & 7.99 & 45 & 81.82 & 10 & 18.18 \\
\hline France & 54 & 7.85 & 53 & 98.15 & 1 & 1.85 \\
\hline Slovakia & 43 & 6.25 & 28 & 65.12 & 15 & 34.88 \\
\hline Netherlands & 32 & 4.65 & 29 & 90.63 & 3 & 9.38 \\
\hline Portugal & 27 & 3.92 & 19 & 70.37 & 8 & 29.63 \\
\hline Croatia & 8 & 1.16 & 4 & 50.00 & 4 & 50.00 \\
\hline Poland & 8 & 1.16 & 6 & 75.00 & 2 & 25.00 \\
\hline Italy & 7 & 1.02 & 5 & 71.43 & 2 & 28.57 \\
\hline Czech Republic & 5 & 0.73 & 2 & 40.00 & 3 & 60.00 \\
\hline Bosnia and Herzegovina & 4 & 0.58 & 4 & 100.00 & 0 & 0.00 \\
\hline Germany & 3 & 0.44 & 3 & 100.00 & 0 & 0.00 \\
\hline Other & 17 & 2.47 & 9 & 52.94 & 8 & 47.06 \\
\hline Total & 689 & 100.00 & 517 & 75.04 & 172 & 24.96 \\
\hline
\end{tabular}

Source: Data acquired by authors

resultsin the research of the Caribbean cruises. In this research, the relation is $75: 24$, which indicates that the number of men increased compared to the results in 2014.

Further analysis will determine the structure of the employees according to gender for specific work positions. At corporate positions (corporate hotel manager, corporate chef), women make $25 \%$, while among the hotel managers there are more women than men (64.29\% to $35.71 \%$ ), as well as among the front office managers. Women are dominant among the head housekeepers, with $84.62 \%$ compared to men, while there are almost no women employed as restaurant managers, executive chefs and captains (except for one woman who is employed as captain). The conclusion is that some positions are being treated as exclu- sively male, probably due to prejudice but also due to the jobs' nature (executive chef, restaurant manager, captain). A higher number of women is evident at managerial positions such as hotel managers, front office managers and head housekeepers.

Based on the structure of the employees according to gender at non-managerial positions, females are prevalent only in housekeeping department. Dragin et al. (2014) had similar results in their research, i.e. they determined that women are more often employed as stateroom attendants and laundry attendants. Dragin et al. (2014) discovered that there are more women than men among bartenders, waiters and chefs de partie while in this research was confirmed that male staff is prevalent in service and kitchen department. In nautical department female staff is not pre-

Table 4. Structure of the employees on the 13 cruise ships analysed according to genderat managerial positions

\begin{tabular}{|l|c|c|c|c|c|}
\hline Position & $\mathrm{N}$ & Male & \% within position & Female & \% within position \\
\hline Corporate manager & 12 & 9 & 75.00 & 3 & 25.00 \\
\hline Hotel manager & 14 & 5 & 35.71 & 9 & 64.29 \\
\hline Front office manager & 14 & 5 & 35.71 & 9 & 64.29 \\
\hline Head housekeeper & 13 & 2 & 15.38 & 11 & 84.62 \\
\hline Executive chef & 16 & 16 & 100.00 & 0 & 0.00 \\
\hline Restaurant Manager & 13 & 13 & 100.00 & 0 & 0.00 \\
\hline Captain & 26 & 25 & 96.15 & 1 & 3.85 \\
\hline $2^{\text {nd }}$ Captain & 26 & 26 & 100.00 & 0 & 0.00 \\
\hline Total & 134 & 101 & 75.37 & 33 & 24.63 \\
\hline
\end{tabular}

Source: Data acquired by authors 
Table 5. Structure of the employees according to gender for non-managerial positions per department

\begin{tabular}{|l|c|c|c|c|c|}
\hline Department & N & Male & \% within position & Female & \% within position \\
\hline Front Desk & 31 & 19 & 61.00 & 12 & 39.00 \\
\hline Entertainment & 15 & 11 & 73.33 & 4 & 26.67 \\
\hline Housekeeping & 99 & 27 & 27.00 & 72 & 73.00 \\
\hline Wellbeing & 17 & 10 & 58.82 & 7 & 41.18 \\
\hline Kitchen & 132 & 123 & 93.00 & 9 & 7.00 \\
\hline Service & 166 & 136 & 82.00 & 30 & 18.00 \\
\hline Nautical & 95 & 95 & 100.00 & 0 & 0.00 \\
\hline Total & 555 & 421 & 75.86 & 134 & 24.14 \\
\hline
\end{tabular}

Source: Data acquired by authors

sent, which is in accordance with the research by Robbins (2009), who determined that men are more often employed as nautical and kitchen staff, compared to women.

When the national structure of the employees at managerial positions is analysed, the results are as follows: most of the employees come from the Netherlands, then France, Romania, Slovakia, Bulgaria and Hungary. Most of the employees from the Netherlands ( 31 employees) and France ( 23 employees) are at the positions as the first and second captain. Only four of the employees who come from the Netherlands are not employed as part of the nautical crew, and only one employee is not at a managerial position. This is a high share of managerial staff for this nationality. If only the employees from the hotel de- partments are analysed, most managers come from Romania (20 employees), which is proportionate with the total share of this nationality within the company. There is one employee on the managerial positions coming from following countries: Spain (Hotel Manager), Austria (hotel manager), Montenegro (purser), Macedonia (purser), Colombia (corporate manager), Poland (hotel manager), and two from Italy (first captain). These employees are presented in the group named 'other' in the figure 1.

Ten years ago, it was also determined that the highest officer positions (the first captain, the second captain), belonged mostly to Romanians. Furthermore, on cruise ships along the Danube, $33.3 \%$ captains come from Romania and $18.3 \%$ come from the Netherlands (Dragin, 2008).

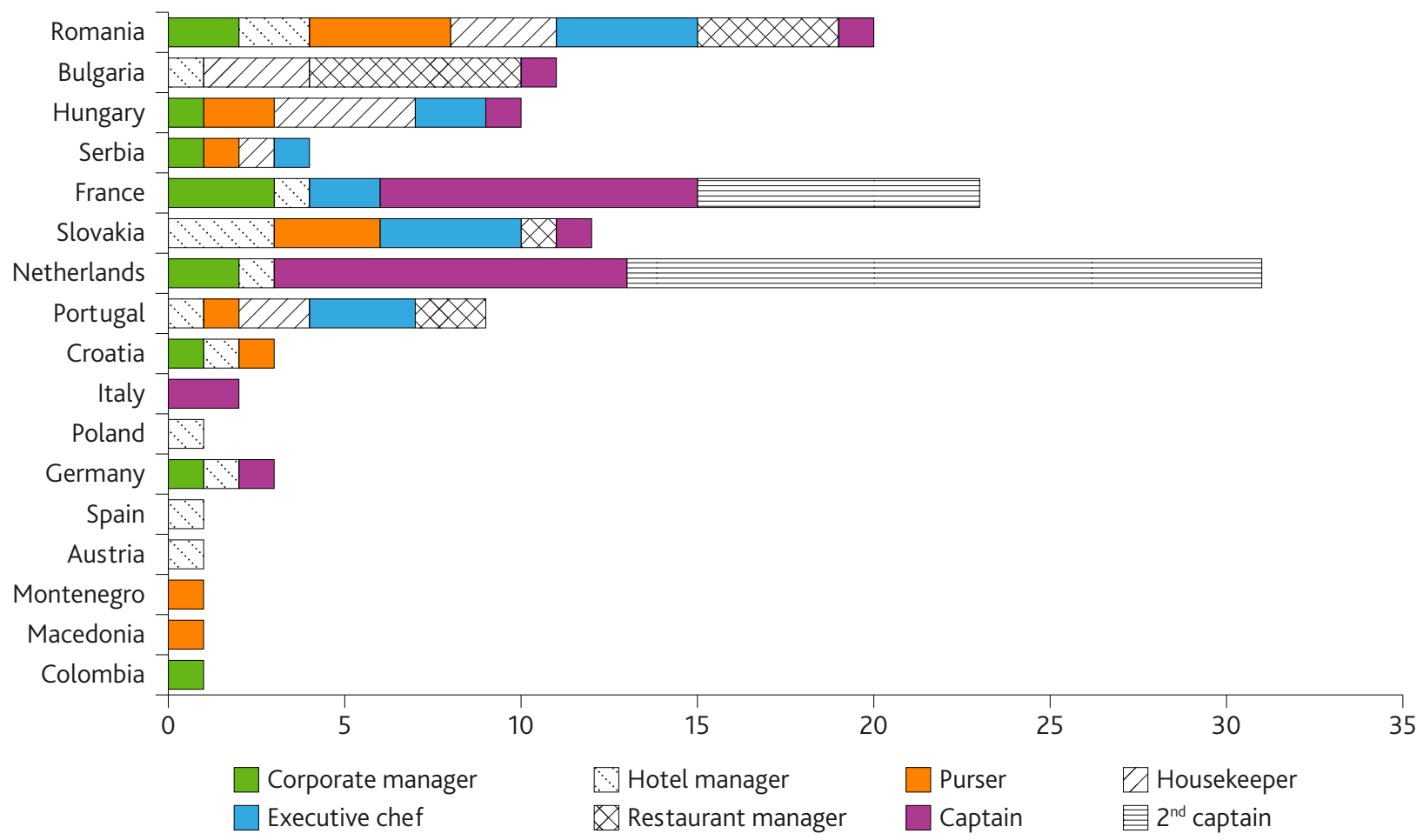

Figure 1. National structure of management on the 13 cruise ships Source: Data acquired by authors 
Based on the interviews with the managers and the non-managerial staff of the cruise ships companies, data was acquired on what the trends are and what challenges the employees in this sector face, as well as how companies compete for the market advantage. It is known that tourism is very sensitive to developments related to the global political and economic scene. According to experts from the river cruising sector, the presidential elections in the USA were one of the factors which kept a number of the USA citizens from travelling. Terrorism is the number one 'enemy' of tourism, and the consequences of terrorist attacks in Paris in 2015 and Brussels in 2016 caused a number of travels to Europe to be cancelled. In order to ensure higher security, the cruising companies have introduced additional security measures, such as constant guarding of the entrance while the ship is in dock, locking the entrance door, legitimisation of all who intend to enter the ships, installing monitoring systems, providing special trainings for the employees so they are able to spot irregularities and how to react to it, etc.

Companies are facing challenges when hiring adequate crew, especially late in the season. An increasing number of companies deal with river cruise ships, so it is very important to maintain the competitiveness in this area. Companies offer different packages to their employees, and positioning is based on the image perceived by a potential employee. For this purpose, companies use popular social networks, the attractive Learning and Development programs, employee branding, certificates of organisations such as Investors in People (this is typical for hotels, while the "Uniworld" is the only accredited company among the companies which deal with river cruise ships). These organisations examine the company's work conditions and management. "Successful accreditation against the Investors in People Standard is the sign of a great employer, an outperforming place to work and a clear commitment to sustainability".

Another way for the company to maintain the standard level in providing services is to hire agencies which offer services such as 'mystery shopper' - a person employed to test the service in shops and businesses by pretending to be a regular customer, in order to achieve consistency and unbiased perception of the service. Innovations and investing into new services, adapting the product to new market demands, and consideration for demand are very important tools for successful business management and competitiveness. Thus, multigenerational cruises, the medcruises and others have been created.

\section{Conclusion}

The results of this study show that the structure of tourists is changing. In the previous period the most prevalent group of tourists on cruise ships were "baby boomers", while recently a new group of millennials appeared. Millennials have a profound "thirst" for adventure and travel, they use the latest technology and social media where they happily post their experiences, sharing them with a large number of friends, having the need to co-create experiences and feeling responsibility to provide feedback to the company on their positive or negative experience.

Most employees on cruise ships come from Romania, Bulgaria, Hungary, Serbia and Slovakia, but a significant share of employees come from France and the Netherlands, typically at managerial positions at the nautical department. Among the employees in the hotel department, most managers are Romanian, then Slovakian, Bulgarian, Hungarian and Portuguese. The employees from Serbia are on the fourth place, but the number of managers is disproportionate to the share of the total number of Serbian employees in the company. Certainly, this information should be accepted cautiously, as Serbs who own Croatian and Hungarian passports do not state Serbian nationality in their job application in order to facilitate administration procedure.

Most employees are male and there is a clear tendency that certain departments are exclusively or mainly appealing to males (nautical, kitchen) while certain positions and departments are appealing to females (hotel manager, front office manager, head housekeeper and housekeeping department generally).

After interviewing the crew at the highest positions, the complexity of business management on river cruises has become evident. It is clear that companies are trying to adapt the existing product to the preferences of increasing demand, but also to create a new product in order to maintain competitiveness. Future research should venture into deeper examination of the social and demographic characteristics of employees and extend the research to more companies who deal with organising cruises.

\section{Acknowledgment}

This paper is a part of research for $\mathrm{PhD}$ thesis of co-author Irma Erdeji. The authors express their gratitude to the company "Uniworld"which enabled access to data on their employees on 13 river cruise ships: River Ambassador, River Baroness, River Beatrice, Super Ship Maria Theresa, River Countess, River Duchess, River Empress, River Queen, River Princess, Super 
Ship Antoinette, Super Ship Catherine, Super Ship Joie de Vivre and River Royale. The authors would also like to express their gratitude to the employees who took part in the research, especially: the Executive Chef Daniel Mikšić, the Senior Vice President of Operations Ben Wirz, the Director Hospitality Michael Teller, the Senior Manager Learning and Development Emilia Madrigal, the Charter Operations/ Learning and Development Manager Julie Higgins.

\section{References}

Bolton, R. N., Parasuraman, A., Hoefnagels, A., Migchels, N., Kabadayi, S., Gruber, T., Solnet, D. 2013. Understanding Generation $Y$ and their use of social media: a review and research agenda. Journal of Service Management, 24, 245-267.

Braun, B., Xander, J., White, K. 2002. The impact of the cruise industry on a region's economy: a case study of Port Canaveral, Florida. Tourism Econo$m y, 8,281-288$.

Brida, J. G., Aguire, S. Z., 2008. The Impacts of the Cruise Industry on Tourism Destinations (Research Unit on Sustainable Development). University of Milano Bicocca, Italy.

Brown, D. J., King, J. B. 1982. Small business ethics: Influences and perceptions. Journal of Small Business Management, 20, 11-18.

Cartwright, R., Baird, C. [eds.] 1999. The development and growth of the cruise industry. ButterworthHeinemann, Waltham, 303 pp.

Dickinson, R. H., Vladimir, A. N. [eds.] 1997. Selling the sea: an inside look at the cruise industry. John Wiley and Sons, Hoboken, 352 pp.

Dragin, A. 2008. Međunarodna krstarenja Koridorom 7 i nautički turizam Srbije (Unpublished Doctoral Dissertation). Prirodno-matematički fakultet, Departman za geografiju, turizam i hotelijerstvo, Novi Sad, 1-228.

Dragin, A. 2010. Krstarenja Koridorom 7. Prirodnomatematički fakultet, Departman za geografiju, turizam i hotelijerstvo, Novi Sad.

Dragin, A., Bubalo-Živković, M., Ivanović, Lj. 2009. The Romanian crew on international cruises along the Corridor VII. Geographica Timisiensis 18, 5766.

Dragin, S. A., Dragin, V., Plavša, J., Ivkov, A., Djurdjev, S. B. 2007. Cruise Ship Tourism on the Danube in Vojvodina Province as a Segment of Global Tourism. Geographica Pannonica 11, 59-64.

Dragin, A., Ivkov, A., Dragin, V. 2006. Nautical tourism as development potential of the Danube countries in South Eastern Europe. Danubius Pannonico Mysicus, Space of Challenges, September $29^{\text {th }}-$ October $2^{\text {nd }}$, Novi Sad, Serbia.
Dragin, A., Jovičić, D., Bošković, D. 2010. Economic Impact of Cruise Tourism along the Paneuropean Corridor VII. Economic Research - Ekonomska Istraživanja, 23, 127-141.

Dragin, S. A., Djurdjev, S. B., Armenski, T., Jovanovic, T., Pavic, D., Ivkov-Dzigurski, A., Kosic, K., Favro, S. 2014. Analysis of the labour force composition on cruise ships: The Danube through Central and Southeast Europe. Journal of Transport Geography, 39, 62-72.

Duman, T., Mattila, A. S. 2005. The role of affective factors on perceived cruise vacation value. Tourism Management, 26, 311-323.

Dwyer, L., Forsyth, P. 1996. Economic impacts of cruise tourism in Australia. Journal of Tourism Studies, 7, 36-43.

Dwyer, L., Forsyth, P. 1998. Economic significance of cruise tourism. Annals of Tourism Research, 25, 393-415.

Foster, G. M. 1986. South seas cruise: a case study of a short-lived society. Annals of Tourism Research, 13, 215-238.

Gabe, T. M., Lynch, C. P., McConnon, J. C., 2006. Likelihood of cruise ship passengers return to a visited port: the case of Bar Harbor, Maine. Journal of Travel Research, 44, 281-287.

Gibson, P. [ed.] 2012. Cruise Operations Management: Hospitality Perspective. Routledge, Taylor \& Francis group, New York, 312 pp.

Hobson, J. P. 1993. Analysis of the US cruise line industry. Tourism management 14, 453-462.

Jaakson, R. 2004. Beyond the tourist bubble? Cruise ship passengers in port. Annals of Tourism Research, 31, 44-6o.

Larsen, S., Wolff, K., Marnburg, E., Ogaard, T. 2013. Belly full, purse closed: cruise line passengers' expenditures. Tourism Management Perspectives, 6, 142-148.

Li, X., Petrick, J. F. 2008. Examining the antecedents of brand loyalty from an investment model perspective. Journal of Travel Research, 47, 25-34.

Li, X., Sanders, K., Frenkel, S. 2012. How leader-member exchange, work engagement and HRM consistency explain Chinese luxury hotel employees' job performance. International Journal of Hospitality Management, 31, 1059-1066.

Mescon, T., Vosikis, G. 1985. Economic impact of tourism at the port of Miami. Annals of Tourism Research, 12, 515-528.

Robbins, D. 2009. Cruising in the global economy: profits, pleasure and work at sea. Tourism Management 30, 775-777.

Schneider, B., Bowen, D. E. [eds.] 2010. Winning the service game. In Handbook of service science. Springer US, pp. 31-59. 
Veronneau, S., Roy, J. 2009. Global service supply chains: an empirical study of current practices and challenges of a cruise line corporation. Tourism Management, 30, 128-139.

\section{$\approx$}

Internet 1: https://www.statista.com/statistics/270605/ cruise-passengers-worldwide/ (19.11.2016).
Internet 2: http://www.history.com/topics/babyboomers (15.01.2017).

Internet 3: http://www.millennialmarketing.com/ who-are-millennials/ (10.01.2017).

Internet 4: http://www.cntraveler.com/galleries/2014-10-20/top-ruise-lines-readers-choiceawards-2014 (6.02.2017).

Internet 5: http://www.cruisecritic.com/ (15.01.2017). 